\title{
Expectations of Pregnant Women and Partners Concerning their Participation in Humanized Births ${ }^{1}$
}

\author{
Joéli Fernanda Basso ${ }^{2}$ \\ Marisa Monticelli ${ }^{3}$
}

Through the theoretical-methodological support of the Liberation Pedagogy, this convergentcare study identified the expectations of pregnant women and their respective partners concerning their participation in humanized birth. Five categories emerged during an educational intervention carried out with groups: choosing the type of delivery; selecting the type of obstetrical care; acknowledging oneself as a critical subject of one's own reality; negotiating with the health team; and acquiring knowledge concerning the delivery process. The study reveals that even though power relations permeate the interactions experienced within healthcare facilities, liberating educational practices can strengthen individuals so they are able to overcome the status quo and transform their obstetrical situation.

Descriptors: Humanizing Delivery; Pregnant Women; Health Education; Sensitivity Training Groups; Obstetrical Nursing.

\footnotetext{
${ }^{1}$ Paper extracted from Master's Thesis "Reflexões de um grupo de gestantes e acompanhantes sobre a participação ativa no parto e nascimento" presented to Nursing Graduate Program, Universidade Federal de Santa Catarina, Florianópolis, SC, Brazil.

2 M.Sc. in Nursing, Consultant, Centro de Tecnologia do Social do Serviço Social da Indústria do Estado de Santa Catarina, Brazil. E-mail: joelifb@gmail.com.

${ }^{3}$ RN, Ph.D. in Nursing, Associate Professor, Universidade Federal de Santa Catarina, Florianópolis, SC, Brazil. E-mail: marisa@nfr.ufsc.br.
}

Corresponding Author: Joéli Fernanda Basso Rua Salomé Damázio Jacques, 90 Ap. 604 Trindade

CEP: 88036-650 Florianópolis, SC, Brasil E-mail: joelifb@gmail.com 


\section{Expectativas de participação de gestantes e acompanhantes para o parto humanizado}

Estudo convergente-assistencial teve como objetivo identificar expectativas de participação de gestantes e acompanhantes para o parto humanizado, sob suporte teóricometodológico da Pedagogia Libertadora. Da prática educativa com grupos emergiram informações que culminaram em cinco categorias: a escolha pelo tipo de parto, a seleção do tipo de atenção obstétrica, o reconhecimento de si como sujeito crítico perante a realidade, a negociação com os profissionais de saúde e a construção de um saber próprio acerca do parto. O estudo permite compreender que, apesar de as interações vivenciadas dentro das instituições de saúde serem permeadas por relações de poder, práticas educativas libertadoras podem contribuir para o fortalecimento dos sujeitos rumo à superação desse status quo e para a transformação da realidade obstétrica.

Descritores: Parto Humanizado; Gestantes; Educação em Saúde; Grupos de Treinamento de Sensibilização; Enfermagem Obstétrica.

\section{Las expectativas de participación de mujeres embarazadas y sus acompañantes para realizar un parto humanizado}

Se trata de un estudio convergente-asistencial que tuvo como objetivo identificar las expectativas de participación de gestantes y acompañantes para realizar un parto humanizado, utilizando el marco teórico metodológico de la Pedagogía Libertadora. De la práctica educativa, con grupos, emergieron informaciones que culminaron en cinco categorías: la elección del tipo de parto, la selección del tipo de atención obstétrica, el reconocimiento de sí misma como sujeto crítico frente la realidad, la negociación con los profesionales de la salud, y la construcción de un saber propio acerca del parto. El estudio permite comprender que, a pesar de que las interacciones experimentadas dentro de las instituciones de salud están compenetradas por relaciones de poder, las prácticas educativas libertadoras pueden contribuir para el fortalecimiento de los sujetos para superar ese status quo y para transformar la realidad obstétrica.

Descriptores: Parto Humanizado; Mujeres Embarazadas; Educación en Salud; Grupos de Entrenamiento Sensitivo; Enfermería Obstétrica.

\section{Introduction}

The birth process has gradually suffered direct, and oftentimes perverse, influence from hospitalcentered culture. The reorganization of care, especially from the $19^{\text {th }}$ century on, established a pathological connotation to an event, which up to that moment, was characterized as a biological and social event(1). In Brazil, the medicalization of this event has contributed to raising the official indexes of the Ministry of Health $(\mathrm{MH})$, particularly those related to $\mathrm{C}$-sections, which causes discomfort, especially in a time when humanizing policies are gaining momentum in the public health system. It also has repercussions for social movements concerned with health care focused on safety and respect for the human being ${ }^{(2)}$, as is the case of the Movement for the Humanization of Labor and Delivery (MHLD).

This issue is also part of the work context of the present authors, who perceive that in the care delivered to women and their companions during labor; they do not always play an active role in the delivery process, allowing professionals to decide for them the best conduct or procedure to be implemented during their hospitalization in maternity. This apparently uncritical 
"surrender" to or acceptance of a situation that contravenes their rights has, for a long time, puzzled the authors. The reason is that the majority of pregnant women and their partners have received orientation and preparation for the experience of birth through educational groups directed at pregnant women, and the institution itself is guided by a philosophy grounded in a humanized perspective of labor and delivery care.

Since 1996 the University Hospital at the Federal University of Santa Catarina (UH/FUSC) has provided an educational course for groups of pregnant women and/or pregnant couples. This course is comprised of eight meetings of four hours each and aims, among other things, to provide health education to prepare pregnant women and their partners for labor and delivery. The autonomy of these individuals depends on how strengthened they are to acknowledge their own rights and demand that these be respected ${ }^{(3)}$, and to make decisions jointly with health professionals. Couples and families who have the opportunity to discuss their doubts ahead of time, explore the various perspectives on actions that are performed in obstetrical centers and also have the opportunity to discuss issues in which they are interested, are more secure in participating in the decision-making process concerning proposed obstetrical procedures or to question those that are imposed.

Another perspective on this issue is related to recent studies on humanized birth published in indexed nursing journals, in which one observes the great quantity of studies addressing issues, conceptions and difficulties faced by obstetrical nurses and midwives, who promote the humanization of care delivered to women and their families, from prenatal care to post delivery ${ }^{(4-7)}$, and also studies largely addressing recent trends to incorporate this paradigm of labor and delivery $\operatorname{care}^{(8)}$. However, there is an important gap in the perspectives of the users of these health services concerning this paradigm. For this reason, we believe this study can contribute to the production of knowledge in the field, especially in relation to the understanding that pregnant women and their partners hold concerning their participation in this process in order to strengthen these ideas through critical reflection facilitated by professionals who work in prenatal health care programs.

Given these questions, this study identifies the expectations of pregnant women and their partners concerning their participation in humanized delivery. A problematizing methodology ${ }^{(3,9)}$ developed in-group and included in the context of a Convergent-Care Study $(\mathrm{CCS})^{(10-11)}$ was used to collect data.

\section{Theory and Methodology}

A CCS was developed because this qualitative mode of research has as its main characteristic the direct and intentional connection with the care and/or educational practices of nurses in their work places. It is a resolution-oriented method, a method focused on minimizing problems faced by nurses in their practice and on possibilities of changing and introducing innovating healthcare practices ${ }^{(10)}$. To achieve the study's objectives, a problematizing educational intervention( ${ }^{(9)}$ was developed with groups of pregnant women and their respective partners. The information necessary to answer questions processed in this study was collected through this intervention ${ }^{(10)}$.

This intervention was chosen to be the study's operational and theoretical supply source because it was organized in order to identify the expectations of pregnant women and their partners concerning their participation in humanized delivery at the same time as it encouraged these individuals to look critically at and discuss the reality of obstetrical care.

The study's participants were those individuals who participated in the courses directed at pregnant women and/or pregnant couples at the UH/FUSC. The CCS was systematically conducted during two courses through two educational interventions (one in each group). The number of participants was not previously established and pregnant women and their partners voluntarily registered for the courses after they were informed via posters displayed on the FUSC's premises. The first educational intervention was carried out from August to September with 21 participants and the second, from October to December 2006 with 30 participants, totaling 51 subjects ( 35 pregnant women and 16 companions). The companions were the women's partners, husbands or friends.

To implement the problematizing education as a way to collect data and aiming to meet the CCS objectives, nine workshops were carried out with each group through an educational process guided by the assumptions of the Liberation Pedagogy(3) and the "umbrella" of problematization, put into operation in five stages. The $1^{\text {st }}$ stage included the experiences of pregnant women and their companions, who were encouraged to express their perceptions concerning labor and delivery, choosing subjects of primary importance to be discussed in the next workshops. In the $2^{\text {nd }}$ stage, key-points of the discussed subjects were pointed out, highlighting what was significant for the group. It was a moment to 
synthesize and collectively seek solutions for the main problems. The $3^{\text {rd }}$ stage consisted of the appropriation of theoretical and practical tools necessary to solve the problems indicated by the group and which were based on their experiences. In the $4^{\text {th }}$ stage, the participants formed hypotheses for solutions, which allowed analyzing the feasibility of proposed actions. The $5^{\text {th }}$ stage consisted of a collective exercise of reflection, where the women and their companions, based on the hypotheses they considered feasible, dialogued about the possibilities of intervening in decisions made during the prenatal period. They also discussed their future experiences to occur during labor and delivery, at the point of their hospitalization in the maternity. The expectations of the groups concerning this moment were then analyzed. Data were collected from the reports the women and their companions provided during these workshops. The workshops were recorded for later transcription; data related to the theoretical-methodological aspects involved, dialogues and discussions about the themes that interested the participants in addition to the interactions that occurred during these meetings were recorded in a field diary.

The corpus of the reports of all pregnant women and their companions were the basis for data analysis. Analysis was longitudinal and sought to interpret, in light of the Liberation Pedagogy, the most significant reports in relation to the study's objectives. This task involved the process of grasping meanings, synthesis and theorization proposed by the $\operatorname{CCS}^{(10-11)}$. In the first step, the statements obtained during the workshops were skimmed and key words were highlighted aiming to meet the study's objectives. Synthesis involved deeper readings of data in order to connect common or contrasting information, which resulted in the delineation of some codes that formed the basis for the development of categories. They were sets of expressions with similar characteristics, or which had something in common given the study's objectives. The third step refers to theorization where these categories were interpreted according to the theoretical framework of the study ${ }^{(10)}$.

In accord with ethical precepts for studies involving humans, the individuals voluntarily participated in this study and were identified by names of flowers. The workshops were carried out after the participants signed free and informed consent forms. The project was approved by the Committee for Research Ethics Concerning Human Subjects at the FUSC, protocol No. 235/2006.

\section{Results and discussion}

Analysis was based on five categories that emerged from data collected during the educational intervention. These categories clarify that women and their companions intend to contribute to hospital births being humanized given the following actions/expectations: 1) choosing vaginal birth as the first option; 2) selecting the type of obstetrical care to guide prenatal care and delivery; 3) acknowledging oneself as a critical subject of one's own experience; 4) negotiating and dialoguing with the health team about preferences concerning obstetrical procedures; 5) and acquiring knowledge about the delivery process.

\section{Choosing vaginal birth as the first option}

Most of the women and their companions reported preferring vaginal birth, which is contrary to the high number of surgical births performed in Brazil and corroborates the findings of other studies in which "the absolute majority of Brazilian women indicate vaginal birth as the best option"(12). The individuals' choices were backed up by the statement that delivering a baby is a physiological phenomenon ${ }^{(1)}$. Opposing their choices to those in the national context, they concluded that the high indexes of surgical births are more related to the choices of professionals than to the will of women and men who experience the process.

I'm considering having a natural birth, I'm preparing myself for that. Natural and active, with no anesthesia or surgical procedures (Orchard).

We realize that there are other interests involved when the physician does C-sections. It is not only the risk involved. Sometimes, it's because it is faster, more convenient for the professional himself. We have to pay attention. In our case, if our desire is taken into account, we prefer a normal delivery (Jasmine's companion)

They also stated that to achieve these expectations, they have to be physically prepared and create a body of knowledge that allows them to understand and accept (if it is the case) potential changes in the process.

[...] I want to try normal delivery, but I want to know everything about the development of labor, to understand the reasons that lead to a $C$-section [...] because if I have to have a C-section, I want to participate as much as I can, deciding everything I can. I guess that the body has to be prepared for both types of delivery, because you become physically and emotionally stronger [...] (Freesia). 
Exercises help women face their fear of labor pain, of not being able to deliver the baby [...]. So, getting prepared through body movements, before labor, it seems to me that the woman gets calmer and more confident in her ability to deliver. It will enable her to be more participative there, when the time arrives [...] (Alpina's companion).

This "modern" conception of re-appropriating birth, of actively experiencing it, is understood as a privilege of small segments of the population, who belong to a more favored social class and have access to varied sources of information, grounded on an alternative or naturalist strand of thought ${ }^{(13)}$. From this perspective, the MHLD encourage the recovery of feminine powers and knowledge that the civilizing process somewhat eliminated, constructing a type of "delivery pedagogy" where women belonging to urban intellectualized segments of the population seek, through preparatory courses, to learn how to deliver a baby ${ }^{(13-14)}$. Most of the study's participants and their companions (77.1\%) are included in this segment: they either have a bachelor's degree or are graduate students.

Even though they belong to this segment, are stimulated to face birth as a physiological event and try to prepare themselves for that, both the women and their companions acknowledge surgical delivery as a safe alternative for situations involving risk. The collective experience and dialogues led to the understanding that this eventuality should be acknowledged by all, not only by the professionals in the delivery room, but mainly by the mothers-to-be and their respective significant ones accompanying them through labor.

\section{Selecting the type of obstetrical care to be provided during prenatal and delivery}

From the perspective of the participants, being subject to obstetrical care that meets their expectations during prenatal care and delivery implies selecting professionals and healthcare facilities that respect their decisions. Even though they acknowledge that the relationship between a professional and a client is a complex one that involves power relationships, they understand that health professionals and the institutions they represent are (or should be) "service providers", in a clear reference to the attitude adopted by some technicians and specialists in the health field with relation to the users of the system.

To meet this expectation, the HM launched a strategy of action called Prenatal Humanization Program in 2000, which intended to standardize professional activities within health institutions, in order to deliver safe and comfortable care, aiming at the integrality ${ }^{*}$ of obstetrical care (as a service delivery), establishing women's rights as institutional guidelines ${ }^{(14)}$. However, we observed through dialoguing with these women and their companions, that these recommendations are not totally established for the final consumer, which contributes to perpetuating inequalities in obstetrical care and characterizes maternity as a phenomenon marked by social, racial and ethnic inequalities ${ }^{(15)}$.

[...] I guess that it is hard to say that the situation of current healthcare is a problem for everyone. I guess that certain professionals [...] Fiefdoms of knowledge still interfere in health institutions, whether it is in the individualized way of treating people, or developing authoritarian institutional philosophies. So, this is when we choose [...] Like, I understand that we should always try to negotiate, but we need to analyze with whom and where we are negotiating (Blue's companion).

The physician with whom I started my prenatal care wasn't nice either. She wears glasses [...] So I'd ask questions and she'd slide her glasses half way down her nose and look at me over them. Like: Why don't you know this? (Hydrangea)

Even with these "obstacles", once pregnant women and their companions acknowledge the influence of institutional routines on obstetrical care and their indexes, and also consider that the Ministry recommendations can ensure labor and delivery that corresponds to their expectations, they believe they can choose the obstetrical care that will be delivered to them, analyzing whether they follow purely interventionist routines or acknowledge and comply with Ministry recommendations.

In fact, things always happen at a macro level. The actions of the professional caring for us are part of an institutionalized routine, which reflects society and its policies [...] so if we think about the way labor and delivery occur in our context, we perceive that we need to seek information for our rights to be respected, because, as we've already mentioned, they are legally guaranteed. Whether in a public or private context, what are the primary interests of that facility? The indexes of surgical births in the private system are there for us to reflect upon [...] I guess that we can choose the care we want to have [...] it's just a matter of looking at reality, reflecting upon it and showing we're aware of our rights [...] (Bromeliad).

People have not yet realized that they don't need to accept this situation, they can choose a kind of care that meet their desires, we can [...] (Acacia's companion).

They emphasize that it is possible for them to choose the obstetrical care that will be delivered during their prenatal period and also the health professional and

* TN: In the context of the Brazilian public health system, integrality refers to the idea that individuals are historical, social and political subjects and should be considered as a whole during the care delivery process. 
facility that corresponds to their expectations even if these are complex issues permeated by diversified interests.

\section{Acknowledging oneself as a critical and reflective subject of one's own reality}

Exercising critical thinking during the workshops allowed the women and their companions to see delivery as a social event. Based on the theoretical reflections about longitudinal transformations experienced in this event and their inclusion as subjects of their own histories, they believe they will awake for a more complex and multi-dimensional reality and will also participate in the recovery process of what they acknowledge as a physiological birth, even if they need to be subject to more invasive procedures.

When they reflect on economic and biomedical interests that disseminate technology and professional control over the birth process, they report they need to be prepared in order to ensure that their "desires" are respected. According to this understanding, strengthening these women and men experiencing this process will enable them to recovery feminine and family control over their delivery, which was lost due to its medicalization ${ }^{(1)}$.

[...] if we evaluate birth as it currently occurs, we realize that we need to seek information so that our will is respected. Birth was previously performed at home and we had strength and wisdom to deliver a baby, then birth become to be performed in hospitals and then women lost everything? Isn't that contradictory?[...] (Bromeliad's companion).

They understand that it is not enough to seek information and knowledge to experience labor and delivery that correspond to their expectations, rather they also need to acknowledge the different intentions (concealed most of the time) permeating this process. They believe that the means of communication can "disguise" the economic interests linked to the birth process as a whole, and sell practicality to less informed individuals.

The active interpretation of the study's participants clearly reproduces the ideas impregnated in the current Brazilian policy concerning labor and delivery care, in the World Health Organization recommendations, in movements of organized social groups and attitudes adopted by various health professionals who fight for care policies promoting respectful labor ${ }^{(16)}$. For these women and their companions to be prepared for that, they dialogued about legal aspects, such as maternity leave and facilities currently offered to workers who breastfeed and their right to have a companion during the entire hospitalization period.

I guess it's important to discuss our rights. Otherwise, how can we demand them so as to experience satisfactory deliveries? (Magnolia).

We must equip ourselves with the weapons we have: knowing the legal issues, the right to have a companion, postpartum-leave, breastfeeding... (Rocket larkspur's companion)

I was thinking about it. What is best is a relative concept, right? (Referring to products sold for baby care). Because it depends on the theory the professional is using. If he believes in that, automatically he considers that to be the best. It's just thinking that, if a physician who only performs C-sections writes a paper about the best type of delivery, for instance, it will be C-sections. Now, if you seek information on a website that favors natural births, the content you'll find will be very different. So you have to be aware of what to look for or at least be aware of interests concealed in a text if it ends up in your hands [...] so we can negotiate with the team and buy the products we deem to be the best, according to the view we have of the birth (Rose's companion)

They concluded that some difficulties will always occur and that their voices will not always be listened to but as they acknowledge themselves as reflective subjects in the face of reality, as they use critical sense to perceive the purposes of products and services offered for their "consumption", as they acknowledge their rights as citizens and are able to act as protagonists and be coresponsible with the team, they will be able to participate in hospital labors and births, actively strengthening the ideals of humanization.

\section{Negotiating and dialoguing with the health team about their preferences concerning obstetrical procedures}

After acknowledging that there are alternatives for the care of women and childcare in maternity other than the hegemonic ones, the women and their companions started to evaluate the possibilities they have to effectively change their current reality, when the day ultimately arrives.

"Negotiating" for them means to dialogue and decide jointly with the health team, making shared decisions about the obstetrical procedures to be performed during hospitalization. Dialoguing and negotiating obstetrical practices between users and professionals is a consequence of the MHLD's ideals and consequent incorporation of citizens' rights into public health policies ${ }^{(17)}$. 
[...] I guess I'd like to choose a lot of things during labor, you know? (Referring to the obstetrical procedures). We intend to talk a lot with the team. Negotiate... I now realize it is possible (Lily's companion).

The participants understand dialogue is an essential tool during this "service delivery", called prenatal care, since this dialogue impedes professionals from having total control over labor and birth, redefining roles and responsibilities, which according to the participants avoid the occurrence of sad and violent experiences.

The histories of veiled violence to which many women and men are subject to during labor inside health facilities, seem to have elicited ambiguous feelings from the participants. In a tangle of ideas, sometimes they believe in a horizontal and respectful relationship between them and health professionals, and sometimes they fear to be victims of vertical and authoritarian relationships, since violence still exists in the Brazilian health services ${ }^{(18)}$. To oppose this fact, they manifest understanding of the reality as a dynamic context that it is possible to change. They realize there is hope in the face of what is already in place and conceive dialogue is a tool that can enable changes.

I guess that dialogue is the only weapon we have for when we are there (the maternity department), I guess that we have to talk to the team the entire time. I guess it is a pacifistic possibility to demand our rights, you know? (Calendula).

We have the right to information, whether in the public or private system. And of course, the way we'll be cared for as well. It is a matter of demanding it (Blue's companion).

Dialogue leads human beings to reflections that can promote them as active and participatory agents of their own histories(3). Their participation in the construction of their history, democratically demanding their rights, participating in decisions and socializing knowledge is strictly related to the idea of citizenship(19-20). Thus, when they show signs that they intend to negotiate and dialogue with heath professionals about obstetrical procedures, they stress they claim their desires and take responsibility for part of the process.

\section{Constructing their own knowledge about the delivery process}

Acquiring knowledge is understood here as a starting point for having respectful and participatory experiences during institutionalized delivery. This understanding went beyond choosing the type of delivery itself and proved it to be more complex, where they established a new order to think and experience labor. For them, considering a "new way" to deliver a baby implies constructing knowledge that enables them to be protagonists in the entire process. They confirm this "other way" as an active, dialogical and emancipatory activity.

I now realize that we'll have to make many decisions! Not only the type of delivery we want but everything involving labor and birth [...] So this is when I realized the construction of a new way to think about the birth process (Bromeliad).

When they realize they are fully experiencing physical and emotional transformations, they intend, with the construction of a body of knowledge inherent to the process of labor and delivery (that meet the particularities of their conditions), to emancipate or strengthen themselves to superimpose the naïve view that technological and medicalizing development tries to foist on them. Thus, they conclude that they need to get themselves closer to the knowledge of professionals but they can and should re-elaborate it based on their own expectations.

I guess that ideally we should link the knowledge of professionals to our own [...] so we can use what they (professionals) know and have to pass on in our favor, adapting it to our will and needs (Glory Lily's companion).

I realize there are a lot of things I need to know, otherwise I won't be able to have my will respected. I want to know and understand what the physicians think and do, but I have abilities to think by myself and see whether this is good or not for me (Daisy).

One of the concerns that they manifested is related to the nature of information that will ground the "body of knowledge" they intend to develop. They believe that this knowledge will be solid as it emerges from varied sources and is collectively discussed because it will permit them to negotiate professional knowledge with their expectations ${ }^{(1)}$.

\section{Final Considerations}

In the search to understand the expectations of individuals who participated in a preparatory course for labor and delivery concerning what they expect to experience in healthcare facilities/maternities we found results that contradict national statistics. Most of these people report they seek and desire social and physiological birth processes, which contrast with the current reality, where hospital and pathological events are in the majority.

When the participants were invited to reflect upon these divergences, they together developed some ways to overcome them, clearly expressing their real expectations of participation, even though they are temporarily in a medical domain. Unlike the technical and 
compartmentalized view of the biomedical perspective, these social subjects state they value women's "body work", the sociability promoted by meetings with health professionals and the labor process itself as something women, children, companions and other significant people can experience with pleasure. They do want to prepare themselves so as to be able to negotiate care and delivery modalities, not to feel intimidated by professional knowledge and authoritarianism. For that, they stress they need to exert efforts to understand and analyze the biomedical language.

This situation is very interesting since professionals and scholars have, up to this point, published an inverse perspective, that is, it would be the role of professionals to understand the language of patients in order to promote interaction and rapport between professional and client, not the opposite. The women and their companions emphasize that they cannot be naïve in this analysis because, even though they feel strong enough to face asymmetric relationships and are more critical, they are aware of the historical transformations experienced by delivery and the interests influencing it.

Women and companions who participate in the group discussions reveal they view it as critical to acknowledge the huge gap that separate them from their own expectations as users of the current policies directed at women and newborns, though, they also glimpse possibilities to transform this reality.

\section{References}

1. Diniz CSG. Humanização da assistência ao parto no Brasil: os muitos sentidos de um movimento. Ciênc Saúde Colet 2005; 10(3):627-37.

2. Ministério da Saúde (BR). Secretaria de Atenção à Saúde. Departamento de Ações Programáticas Estratégicas. Pré-natal e puerpério: atenção qualificada e humanizada. Brasília (DF); 2005.

3. Freire P. Pedagogia do oprimido. 41 ed. Rio de Janeiro: Paz e Terra; 2005.

4. Guimarães EER, Chianca TCM, Oliveira AC. Puerperal infection from the prespective of humanized delivery care at a public maternity hospital. Rev. Latino-Am. Enfermagem. 2007; 15(4):536-42.

5. Dotto LMG, Moulin NM, Mamede MV. Prenatal care: difficulties experienced by nurses. Rev. Latino-Am. Enfermagem. 2006; $14(5): 682-8$.

6. Couto GR. Conceitualização pelas enfermeiras de preparação para o parto. Rev. Latino-Am. Enfermagem. 2006; 14(2):190-8.

7. Castro JC, Clapis MJ. Parto humanizado na percepção das enfermeiras obstétricas envolvidas com a assistência ao parto. Rev. Latino-Am. Enfermagem. 2005; 13(6):960-7.

8. Merighi MAB, Gualda DMR. Mothers'health in Brazil and recovering the training of midwives for care in the birth process. Rev. Latino-Am. Enfermagem. 2009; 17(2):265-70.

9. Bordenave JD, Pereira AM. Alguns fatores pedagógicos. Capacitação pedagógica para instrutor/supervisor - Área de saúde. In: Ministério da Saúde (BR). Coordenação Geral de Recursos Humanos para o SUS. Brasília (DF): Ministério da Saúde; 1994. p. 19-26.

10. Trentini M, Paim L. Pesquisa convergente-assistencial: um desenho que une o fazer e o pensar na prática assistencial em saúde-enfermagem. 2 ed. Florianópolis: Insular; 2004.
11. Monticelli M. Aproximações culturais entre trabalhadoras de enfermagem e famílias no contexto do nascimento hospitalar: uma etnografia de alojamento conjunto. [tese]. Florianópolis (SC): Programa de Pós-Graduação em Enfermagem/UFSC; 2003.

12. Faúndes A, Pádua KS, Osis MJD, Cecatti JG, Sousa MH. Opinião de mulheres e médicos brasileiros sobre a preferência pela via de parto. Rev Saúde Pública 2004; 38(4):488-94.

13. Tornquist CS. Armadilhas da nova era: natureza e maternidade no ideário da humanização do parto. Rev Estud Fem. julho/dezembro 2002; 10(2):483-92.

14. Barbosa GP, Giffin K, Angelo-Tuesta A, Gama AS, Chor $D$, D'orsi E, et al. Parto cesáreo: quem o deseja? Em quais circunstâncias? Cad Saúde Pública. 2003; 19(6):1611-20.

15. Monteiro MAA, Tavares TJL. A prática do grupo de gestantes na efetivação da humanização do parto. Rev Rene julho/ dezembro 2004; 5(2):73-8.

16. Ministério da Saúde (BR). Secretaria de Políticas de Saúde. Área de Saúde da Mulher. Parto, aborto e puerpério: assistência humanizada à mulher. 2 ed. Brasília (DF); 2003.

17. Casate JC, Correa AK. Humanização do atendimento em saúde: conhecimento veiculado na literatura brasileira de enfermagem. Rev. Latino-Am. Enfermagem. 2005; 13(1):10511.

18. D'Oliveira AFPL, Diniz SG, Schraiber LB. Violence against women in health-care institutions: an emerging problem. Lancet. 2002; 359(9318):1681-5.

19. Acioli MD, Carvalho EF. Discursos e práticas referentes ao processo de participação comunitária nas ações de educação em saúde: as ações de mobilização comunitária do PCDEN/PE. Cad Saúde Pública. 1998; 14(2):559-68.

20. Damasceno AM, Said FA. O método problematizador no cuidado educativo com mulheres no preparo ao parto. Cogitare Enferm. 2008 dezembro; 13(2):173-83.

Received: May. 22 2009

Accepted: Dec. $22^{\text {nd }} 2009$ 